\title{
Standardization, Characterization and Shelf Life Studies on Sandge, a Traditional Food Adjunct of Western India
}

\author{
Renu Khedkar ${ }^{1 *}$, Pratima Shastri ${ }^{2}$, Amarinder Singh Bawa ${ }^{3}$ \\ ${ }^{1,3}$ Amity Institute of Food Technology, AUUP, Noida, U.P., India \\ ${ }^{2}$ Ex. Dept. of Food Technology, LIT, Nagpur, Maharashtra, India
}

\begin{abstract}
Food adjuncts are an assortment of items that add variety, spice and crunch to the common menu. Maharashtra is a western state of India. Traditional food adjuncts of Maharashtra include sandge, sandaya, kurdaya, papad, pickles, chutney and chutney powders, wadi etc. Studies were undertaken to standardize the recipe, process parameters and select suitable packaging materials for Sandge a dried vegetable product made from carrot and /pumpkin/ bottle gourd or radish as well as okra, coriander leaves, sesame seeds, green chilies and salt). Five different combinations using carrot $(80 \%, 60 \%, 40 \%)$, pumpkin / bottle gourd $(20 \%, 40 \%)$ each and other ingredients $(20 \%)$ were prepared and evaluated for sensory characteristics. The product made with carrot (80\%) and other ingredients (20\%) scored the best. The product from standardized recipe was dried at three different temperatures $\left(45^{\circ} \mathrm{C}\right.$, $\left.50^{\circ} \mathrm{C}, 55^{\circ} \mathrm{C}\right) .50^{\circ} \mathrm{C}$ drying temperature was found to be optimum based on the sensory evaluation. The dehydrated sandge were analyzed for their physico-chemical characteristics, packed in PET/PE and PET/Met.poly/PE pouches and stored under ambient temperature conditions for a period of 90 days. The decrease in sensory scores was found to be significant in PET/PE packed sandge while the same packed in PET/Met.poly/ PE pouches was found to be acceptable even after 90 days of storage. The colour changes over the storage period were also measured using Lovibond Tintometer.
\end{abstract}

Keywords- adjunct, carrot, drying, packaging, nutritional composition,sandge, sorption isotherm, sensory values.

\section{INTRODUCTION}

Indian cuisine consists of a wide spectrum of food cultures with distinctive regional difference and preferences [1]. Food adjuncts are an assortment of items that are consumed as an accompaniment to the staple food [2]. They add variety, spice and crunch to the common menu with standard items. Indian cuisine includes a variety of food adjuncts which can be broadly classified into the pickles, chutneys, dry chutney powders, preserves like amlamurabba , dried vegetable products such as sandge and bharwanmirch, dry semi processed adjuncts like papad, urad mung or channabadi, extruded products from cooked starchy materials such as Kurdai from wheat, chikwadi from rice or sorghum, and many more local varieties, which are consumed after frying or are made into curry [3].

Maharashtra is a western state of India. Maharashtrian cuisine is rich and diverse ranging from mild vegetarian food of Pune to spicy dishes from Kolhapur and sea food of kolis and konkanis [4]. Traditional food adjuncts of Maharashtra include sandge, sandaya, kurdaya, papad, pickles, chutney and chutney powders, wadi etc. [5]. These food items are relished along with the traditional staple diet of roti (wheat bread), rice/khichdi (cooked rice+pulses), dal(curry made of pulses) and sabzi (cooked vegetable). Traditionally these products were prepared at household level, by making use of regionally and seasonally available ingredients. Some of the products like wet chutneys and some pickles would have a shelf life of 8-15 days, but most of the products were prepared to ensure the supply throughout the year. Seasonal perishable vegetables would be converted into shelf stable pickles, sauces and spreads. Preparation of dried products like papad, wadi, chips etc. has been a regular activity in early summer, and the practice is still alive in semi urban and rural setup. Increasing urbanization, social changes, and presence of large section of middle class working women with enhanced purchasing power in cities has created the need for supply of these adjuncts as a consumer item. They are being prepared as a local branded/non-branded product at a cottage /small scale industry by needy women as per seasonal demand and sold to nearby grocery outlets or as door to door service. The 
quality parameters for most of these products are not standardized, documented or monitored by any regulatory bodies [3].

Sandgeare dried vegetable products made by mixing grated carrots and /pumpkin/ bottle gourd or radish with okra, coriander leaves, sesame seeds, green chilies and salt; making it into small balls and drying in hot sun for two to three days. The dried balls are then fried and served along with rice, khichdi or added to curries at the time of scarcity of vegetables [6].Sandge available in market from March to May contain varied ingredients and have short shelf life with poor packaging.

\subsection{Nutritive importance}

Although consumed in small portions, adjuncts play an important role in nutrition and health. A major ingredient used in sandge formulations is carrot. Carrot is a root crop. It is widely used in various vegetable preparations, pickles and sweet dishes [7]. According to ministry of agriculture, Govt. of India, in the year 2012-13, the production of carrot in India was 11.47 lakh metric tonnes. There is enough production, but the seasonal availability restricts its use to the season when it is available in plenty [8]. People all over the world prefer the consumption of carrot due to its high nutritive value and medicinal uses for its anti-cancerous property [9]. Carrot has the highest $\beta$ - carotene content $(8285 \mu \mathrm{g} / 100 \mathrm{gm})$ among foods [10]. Carrots are rich in antioxidants (falcarinol), vitamins especially vit. $\mathrm{C}$ and pyridoxine (vit. B6), folic acid, thiamin, pantothenic acid and contain good levels of minerals like copper, calcium, potassium, manganese and phosphorus [11]. Leafy vegetables such as coriander leaves are inexpensive, contain low levels of fat and are rich sources of carotene, ascorbic acid, folic acid, riboflavin, fiber and minerals like calcium, iron and phosphorus [12-15]. Sesame seeds add a nutty taste and crunch to many Asian dishes [16]. They are an important source of fat, protein, dietary fiber, vitamins such as niacin, folic acid, thiamin, pyridoxine, riboflavin and minerals such as calcium, copper, manganese, magnesium, iron, zinc, and selenium. They are also rich source of omega-6-fatty acids, antioxidants such as sesamol and sesaminol [11].

This study was undertaken to standardize the recipe and the process parameters as well as to evaluate nutritive value of the product during storage using different packaging materials.

\section{MATERIALS AND METHODS}

Vegetables like carrot (Daucuscarota), pumpkin (Cucurbita moschata), bottle gourd (Lagenaria vulgaris), coriander

leaves (Coriandrumsativum), fenugreek leaves
(Trigonellafoenum-graecum), green chilies (Capsicum annum), okra were procured from the local vegetable market. All the vegetables were washed under running water till completely free of dirt. Carrots, bottle gourd and pumpkin were peeled and grated using food processor (Inalsa, India). Coriander and fenugreek leaves were separated from the stems, dried on muslin cloth till surface moisture was evaporated and finely chopped. Okra pods and green chilies were chopped and ground to a fine paste.

Sesame seeds(Sesamumindicum) and common salt were procured from the supermarket. Sesame seeds were also cleaned and salt was checked for any impurities.

\subsection{Standardization of recipe and process parameters}

Sandgerecipe was formulated using various levels of carrot (20-80\%), okra, green chilies, coriander leaves, sesame seeds and salt and the best product was obtained for a combination of carrot (80\%), okra (9\%), green chilies $(3.5 \%)$, coriander leaves $(2 \%)$, sesame seeds $(3.5 \%)$ and salt $(2 \%)$. For incorporation of either pumpkin or bottle gourd in the recipe, sandge formulation was made using pumpkin / bottle gourd at $20 \%$ or $40 \%$ levels each, while the levels for carrot were maintained at $60 \%$ or $40 \%$ respectively. The recipe made with carrot at $80 \%$ level was taken as control. The five samples were prepared with the given composition and dried in a tray dryer (SM Scientech, Kolkata) at $50^{\circ} \mathrm{C}$ till constant weight was obtained. Sensory evaluation was performed using nine point hedonic scale with 1 - dislike extremely to 9 - like extremely for the samples by a semi-trained panel of 10 judges [17]. The panelists were earlier made to acquaint themselves with various samples of sandge from the market. The recipe selected on the basis of the sensory analysis was also tested at three different drying temperatures $\left(45^{\circ} \mathrm{C}, 50^{\circ} \mathrm{C}, 55^{\circ} \mathrm{C}\right)$. Results of the sensory analysis standardized $50^{\circ} \mathrm{C}$ as the optimum drying temperature for the recipe. The selection of drying temperature of $50^{\circ} \mathrm{C}$ has been in consensus with Kaur et al. [18].

\subsection{Physico-chemical analysis}

The standardized samples of sandge were analyzed in triplicate for physico-chemical characteristics .Moisture, crude fat, total protein, crude fiber, ash, carotene and salt content were estimated using standard methods [19]. Carbohydrates were estimated by the difference method. Calcium was estimated by gravimetry while iron by spectroscopy using aElico model SL-177 UV-visible spectrophotometer. Energy values were calculated by the standard method of summing up the values obtained and multiplying the quantity of carbohydrate and protein per 
$100 \mathrm{gm}$ by $4 \mathrm{kcal}$ and that of fat per $100 \mathrm{gm}$ by $9 \mathrm{kcal}$ respectively.

\subsection{Sorption studies}

Moisture sorption studies were conducted on the standardized samples of sandge by keeping $5 \mathrm{gm}$ of each of the sample in separate desiccator maintained at different relative humidities e.g. $10 \% \mathrm{RH}, 30 \% \mathrm{RH}, 40 \% \mathrm{RH}, 50 \% \mathrm{RH}$, $60 \% \mathrm{RH}, 70 \% \mathrm{RH}$ and $90 \% \mathrm{RH}$, using varying normality Sulphuric acid solutions at $25^{\circ} \mathrm{C}$ [20]. Sample weights were noted at regular intervals till there was no further loss or gain in weight .Adverse changes like softness, sogginess, discoloration and mold growth were also noted from time to time. Critical moisture content and equilibrium moisture content were determined from the sorption isotherm.

\subsection{Storage studies}

Sandge samples (25gm each) were packaged in PET/ PE $(12 \mu \quad \mathrm{PET} / 50 \mu \mathrm{PE})$ and PET/metallized polyester/polythene $(10 \mu / 10 \mu / 37.5 \mu)$ laminate pouches $(10$ $\mathrm{cm} \times 10 \mathrm{~cm})$. The packaged samples were kept under ambient temperature $\left(15-35^{\circ} \mathrm{C}\right)$ conditions for a period of 90 days. The samples were drawn at an interval of 15 days and evaluated for the sensory quality and compared with a freshly prepared sample. The samples were evaluated for color units of Red, Yellow and Blue using Lovibond Tintometer (model E).

\subsection{Statistical analysis}

The data were expressed as mean \pm S.D. Statistical analysis was carried out with SPSS version 21.0 using one-way ANOVA using followed by Tukey's post hoc test for significance $(\mathrm{P} \leq$. 0.05).

\section{RESULTS AND DISCUSSION}

\subsection{Standardization of recipe of Sandge}

Results of the sensory evaluation from Table 1 indicated that among the formulations, the scores for colour ranged between $5.4 \pm 0.97$ and $8.6 \pm 0.52$. Appearance scores were found to be in the range of $5.9 \pm 0.99$ and $8.1 \pm 0.74$, flavour values ranged between5.9 \pm 0.99 and $8.2 \pm 0.79$, scores for texture between $4.9 \pm 0.74$ and $8.0 \pm 0.82$, taste scored between $4.7 \pm 0.82$ and $8.1 \pm 0.71$, while overall acceptance levels varied between $5.2 \pm 0.92$ and $8.2 \pm 0.63$. Maximum and significantly higher scores for all the parameters i.e. colour, appearance, flavour, texture, taste and overall appearance were obtained for sample containing $80 \%$ carrot. The addition of bottle gourd or pumpkin at a level of $40 \%$ affected all the parameters more significantly than at a level of $20 \%$. Also the sandge with pumpkin or bottle gourd at $40 \%$ were found to be more salty and less crispy. The higher moisture content and low fibre in pumpkin $(92 \%$ moisture content, $0.5 \%$ fibre) and in bottle gourd (96\% moisture content, $0.6 \%$ fibre) than in carrot ( $88 \%$ moisture content, $2.6 \%$ fibre) [21]might be responsible for the saltiness and less crispiness in the product. The higher carotene content of carrots $(5.33 \mathrm{mg} / 100 \mathrm{~g})$ than in pumpkin $(50 \mu \mathrm{g} / 100 \mathrm{~g})$ and in bottle gourd $(0 \mu \mathrm{g} / 100 \mathrm{~g})$ imparted bright red colour to the product. The process for the preparation of standardized Sandge is presented in Fig. 1.

\subsection{Physico-chemical properties of Sandge}

The proximate composition of standardized sandge are reported in Table 2 .Moisture content in standardized sample prior to drying was $92.43 \%$ which reduced to $7.46 \%$ after drying at $50^{\circ} \mathrm{C}$. Crude fat in sandge was found to be 7.12\%. Tadesse, et al. [22] reported the crude fat content of solar dried carrots to be $2.49 \%$ on $\mathrm{db}$. The higher fat content of sandge might be due to the presence of sesame seeds having crude fat content (43-50\%) [23]. The protein content of standardized sandge is $9.23 \%$. The protein content of solar dried carrots is $5.25 \%$. The increase in protein may be because of higher protein content of sesame seeds (15-20\%) and dried okra (16.9-18\%) [24]. Total ash is found to be $20.05 \%$, crude fiber $2.79 \%$ in the standardized sandge. The higher amount of vegetables might be responsible for the higher carbohydrate content of $56.14 \%$.

Wash and clean the vegetables. Peel and grate the carrots. Separate the coriander leaves from stem, Chop and crush okra pods, coriander leaves and green chili into paste

Clean the sesame seeds. Weigh sesame seeds and salt.

Weigh the grated carrots ( $80 \%)$, crushed okra pods $(9 \%)$, green chili paste (3.5\%), sesame seeds (3.5\%), chopped coriander leaves $(2 \%)$ and salt ( $2 \%)$. Mix these ingredients well and make balls of around 2 inch. diameter.

Dry the balls in cabinet dryer at $50 \pm 2^{\circ} \mathrm{C}$ till constant weight

Package in PET/ Metallized polyester/PE laminated pouches and store at $15-30^{\circ} \mathrm{C}$

Fig.1: Standardized process for Sandge preparation 


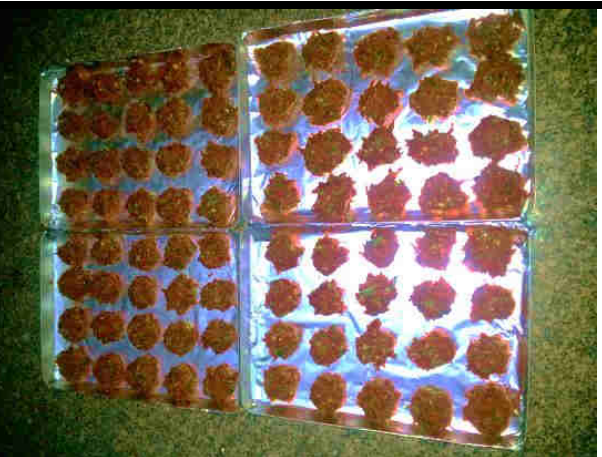

Fig. 2: Sandge samples in trays for drying

Table 1. Sensory scores for selection of carrot and/pumpkin and bottle gourd $(n=10)$

\begin{tabular}{|c|c|c|c|c|c|}
\hline \multirow{2}{*}{ Parameter } & \multicolumn{5}{|c|}{ Scores } \\
\hline & $\begin{array}{c}\text { Sample } \\
1\end{array}$ & $\begin{array}{c}\text { Sample } \\
2\end{array}$ & $\begin{array}{c}\text { Sample } \\
\mathbf{3}\end{array}$ & $\begin{array}{c}\text { Sample } \\
4\end{array}$ & $\begin{array}{c}\text { Sample } \\
5\end{array}$ \\
\hline Colour & $\begin{array}{l}8.6 \pm \\
0.52\end{array}$ & $7.7 \pm 0.95$ & $6.6 \pm 0.97$ & $7.2 \pm 0.92$ & $5.4 \pm 0.97$ \\
\hline Appearance & $8.1 \pm 0.74$ & $7.7 \pm 0.68$ & $6.5 \pm 0.97$ & $7.2 \pm 0.79$ & $5.9 \pm 0.99$ \\
\hline Flavour & $8.2 \pm 0.79$ & $7.6 \pm 0.97$ & $6.6 \pm 0.97$ & $7.1 \pm 0.57$ & $5.9 \pm 0.99$ \\
\hline Texture & $8.0 \pm 0.82$ & $7.3 \pm 0.82$ & $6.1 \pm 0.74$ & $6.9 \pm 0.88$ & $4.9 \pm 0.74$ \\
\hline Taste & $8.1 \pm 0.71$ & $7.3 \pm 0.68$ & $5.8 \pm 0.63$ & $7.0 \pm 0.94$ & $4.7 \pm 0.82$ \\
\hline $\begin{array}{c}\text { Overall } \\
\text { appearance }\end{array}$ & $8.2 \pm 0.63$ & $7.7 \pm 0.82$ & $5.9 \pm 0.88$ & $7.1 \pm 0.57$ & $5.2 \pm 0.92$ \\
\hline Remarks & $\begin{array}{l}\text { Good } \\
\text { taste, } \\
\text { texture, } \\
\text { colour } \\
\text { and } \\
\text { flavour }\end{array}$ & $\begin{array}{l}\text { Colour } \\
\text { pale, } \\
\text { mild } \\
\text { flavour, } \\
\text { less } \\
\text { crispy }\end{array}$ & $\begin{array}{l}\text { Colour } \\
\text { pale, } \\
\text { less } \\
\text { crispy, } \\
\text { slightly } \\
\text { salty }\end{array}$ & $\begin{array}{l}\text { Colour } \\
\text { pale, } \\
\text { mild } \\
\text { flavour, } \\
\text { less } \\
\text { crispy }\end{array}$ & $\begin{array}{l}\text { Less } \\
\text { crispy } \\
\text { and } \\
\text { more } \\
\text { salty }\end{array}$ \\
\hline
\end{tabular}

Values are mean \pm S.D.

Sample 1: carrot $80 \%+$ other $20 \%$

Sample 2: carrot $60 \%+$ pumpkin(20\%)+other $20 \%$

Sample 3: carrot $40 \%+$ pumpkin $(40 \%)+$ other $20 \%$

Sample 4: carrot $60 \%+$ bottle gourd $(20 \%)+$ other $20 \%$

Sample 5: carrot $40 \%+$ bottle gourd $(40 \%)+$ other $20 \%$

Table 2.Physico-chemical characteristics of freshly prepared Sandge (per 100g)

\begin{tabular}{|c|c|}
\hline Parameter $(\mathbf{g})$ & Sandge \\
\hline Moisture & $7.46 \pm 0.07$ \\
\hline Crude fat & $7.12 \pm 0.10$ \\
\hline Ash & $20.05 \pm 1.14$ \\
\hline Total protein & $9.23 \pm 0.11$ \\
\hline Crude fiber & $2.27 \pm 0.09$ \\
\hline
\end{tabular}

\begin{tabular}{|c|c|}
\hline Carbohydrates & 56.14 \\
\hline Energy $(\mathrm{kcal})$ & 325.6 \\
\hline Salt $(\mathrm{NaCl})$ & $10.24 \pm 0.18$ \\
\hline Carotene $(\mathrm{mg})$ & $5.93 \pm 0.17$ \\
\hline Vit.C $(\mathrm{mg})$ & $7.72 \pm 0.12$ \\
\hline Calcium $(\mathrm{mg})$ & $2.79 \pm 0.16$ \\
\hline Iron $(\mathrm{mg})$ & $32.95 \pm 1.19$ \\
\hline
\end{tabular}

Values are average of three replicates \pm S.D.

\subsection{Moisture sorption isotherm}

Moisture sorption isotherm was plotted for sandge as represented in Fig.3. The product had an initial moisture content of $7.57 \%$, which corresponds to $42 \%$ RH. The critical moisture content was found to be $13.5 \%$, which corresponded to $53 \% \mathrm{RH}$, making it unstable at higher relative humidities, being hygroscopic in nature. It gained moisture quickly, became soft and discolored at $\mathrm{RH}$ above $70 \%$.

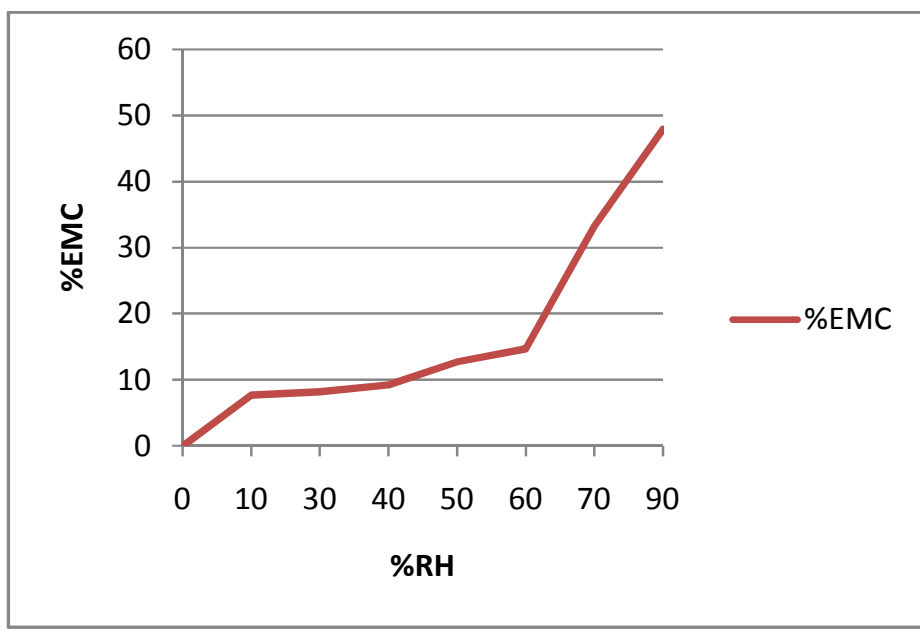

Fig.3: Moisture sorption isotherm for Sandge using sulphuric acid solutions of various $R H$

\subsection{Storage studies}

Table 3 indicates the changes in sensory scores of sandge during storage at ambient conditions for a period of 90 days.During the storage period of 90days, it was observed that the overall sensory quality of sandge was 8.7(excellent) on the 0 day which decreased to 1.7 (bad) for PET/PE packaged samples, whereas for PET/Met.Poly/PE packaged sample it was 8.1 (very good) after 90days. The samples packaged in PET/Met. Poly /PE laminates showed marginal changes in colour, appearance, flavour, texture and taste during the storage study, but the PET/ PE packaged samples had significant changes in all the parameters after a storage period of 30 days. After 45 days, 
the quality of the PET/ PE packaged samples was unacceptable. The samples packaged in PET/Met poly /PE remained in acceptable conditions even after 90days storage. It was statistically proved that the sandge packaged in PET/PE packaging material showed significant $(\mathrm{P} \leq$. $0.05)$ decrease in all the quality parameters where as for the PET/Met. Poly/PE, except for texture, the values for all the sensory parameters were not significantly $(\mathrm{P}>0.05)$ affected. Similar results on metallized polyester packaging were obtained for the storage studies conducted on curry leaves chutney powder by Rao et al. [25] and on the flaxseed chutney powder by Satyanarayanaet al.[26].

Table 3: Sensoryscores of sandgeduring storage at ambient temperature conditions for 90 days $(n=10)$

\begin{tabular}{|c|c|c|c|c|c|c|c|c|c|c|c|c|c|c|}
\hline \multirow{2}{*}{$\begin{array}{c}\text { param } \\
\text { eters }\end{array}$} & \multicolumn{7}{|c|}{ PET/ PE } & \multicolumn{7}{|c|}{ PET/Met poly/PE } \\
\hline & $\mathbf{0}$ & 15 & 30 & 45 & 60 & 75 & 90 & $\mathbf{0}$ & 15 & 30 & 45 & 60 & 75 & 90 \\
\hline Colour & $\begin{array}{c}8.7 \pm 0 . \\
48^{\mathrm{a}}\end{array}$ & $\begin{array}{l}8.5 \pm \\
0.71^{\mathrm{a}}\end{array}$ & $\begin{array}{c}7.8 \pm 0 . \\
92^{\mathrm{a}}\end{array}$ & $\begin{array}{l}5.3 \pm \\
0.95^{\mathrm{b}}\end{array}$ & $\begin{array}{l}3.9 \pm \\
0.74^{\mathrm{c}}\end{array}$ & $\begin{array}{l}2.6 \pm \\
0.84^{\mathrm{d}}\end{array}$ & $1.7 \pm 0.66^{\mathrm{d}}$ & $\begin{array}{l}8.7 \\
\pm 0 . \\
48^{\mathrm{a}}\end{array}$ & $\begin{array}{l}8.7 \\
\pm 0 . \\
48^{\mathrm{a}}\end{array}$ & $\begin{array}{l}8.4 \\
\pm 0 . \\
70^{\mathrm{a}}\end{array}$ & $\begin{array}{c}7.7 \pm 0 . \\
68^{\mathrm{a}}\end{array}$ & $\begin{array}{c}7.4 \pm 0 . \\
84^{\mathrm{a}}\end{array}$ & $\begin{array}{c}6.8 \pm \\
0.79^{\mathrm{a}}\end{array}$ & $6.5 \pm 0.97^{\mathrm{a}}$ \\
\hline $\begin{array}{l}\text { Appear } \\
\text { ance }\end{array}$ & $\begin{array}{c}8.4 \pm 0 . \\
84^{\mathrm{a}}\end{array}$ & $\begin{array}{l}8.3 \pm \\
0.82^{\mathrm{a}}\end{array}$ & $\begin{array}{c}7.5 \pm 0 . \\
97^{\mathrm{a}}\end{array}$ & $\begin{array}{l}5.7 \pm \\
0.82^{b}\end{array}$ & $\begin{array}{l}4.9 \pm \\
0.74^{b}\end{array}$ & $\begin{array}{l}3.7 \pm \\
0.82^{\mathrm{c}}\end{array}$ & $2.0 \pm 0.67^{\mathrm{d}}$ & $\begin{array}{l}8.7 \\
\pm 0 . \\
48^{\mathrm{a}}\end{array}$ & $\begin{array}{l}8.4 \\
\pm 0 . \\
70^{\mathrm{a}}\end{array}$ & $\begin{array}{l}8.2 \\
\pm 0 . \\
63^{\mathrm{a}}\end{array}$ & $\begin{array}{c}7.4 \pm 0 . \\
84^{\mathrm{a}}\end{array}$ & $\begin{array}{c}7.3 \pm 0 . \\
82^{\mathrm{a}}\end{array}$ & $\begin{array}{c}6.8 \pm \\
0.79^{\mathrm{a}}\end{array}$ & $6.2 \pm 0.84^{\mathrm{a}}$ \\
\hline Flavour & $\begin{array}{c}8.7 \pm 0 . \\
48^{\mathrm{a}}\end{array}$ & $\begin{array}{l}8.5 \pm \\
0.71^{\mathrm{a}}\end{array}$ & $\begin{array}{c}7.7 \pm 0 . \\
68^{\mathrm{a}}\end{array}$ & $\begin{array}{c}6.5 \pm \\
0.71^{b}\end{array}$ & $\begin{array}{l}5.5 \pm \\
0.53^{\mathrm{c}}\end{array}$ & $\begin{array}{c}3.7 \pm \\
0.68^{\mathrm{d}}\end{array}$ & $1.8 \pm 0.42^{\mathrm{e}}$ & $\begin{array}{l}8.7 \\
\pm 0 . \\
48^{\mathrm{a}}\end{array}$ & $\begin{array}{l}8.7 \\
\pm 0 . \\
48^{\mathrm{a}}\end{array}$ & $\begin{array}{l}8.6 \\
\pm 0 . \\
52^{\mathrm{a}}\end{array}$ & $\begin{array}{c}8.1 \pm 0 . \\
88^{\mathrm{a}}\end{array}$ & $\begin{array}{c}7.8 \pm 0 . \\
79^{\mathrm{a}}\end{array}$ & $\begin{array}{c}7.5 \pm \\
0.53^{\mathrm{a}}\end{array}$ & $7.3 \pm 0.68^{\mathrm{a}}$ \\
\hline Texture & $\begin{array}{c}8.7 \pm 0 . \\
48^{\mathrm{a}}\end{array}$ & $\begin{array}{l}8.4 \pm \\
0.70^{\mathrm{a}}\end{array}$ & $\begin{array}{c}7.5 \pm 0 . \\
71^{\mathrm{a}}\end{array}$ & $\begin{array}{l}5.8 \pm \\
0.92^{b}\end{array}$ & $\begin{array}{l}4.6 \pm \\
0.52^{c}\end{array}$ & $\begin{array}{l}2.5 \pm \\
0.71^{\mathrm{d}}\end{array}$ & $1.5 \pm 0.53^{\mathrm{e}}$ & $\begin{array}{l}8.7 \\
\pm 0 . \\
48^{\mathrm{a}}\end{array}$ & $\begin{array}{l}8.5 \\
\pm 0 . \\
53^{\mathrm{a}}\end{array}$ & $\begin{array}{l}8.1 \\
\pm 0 . \\
57^{\mathrm{a}}\end{array}$ & $\begin{array}{c}7.8 \pm 0 . \\
63^{\mathrm{a}}\end{array}$ & $\begin{array}{c}7.6 \pm 0 . \\
52^{\mathrm{a}}\end{array}$ & $\begin{array}{c}6.9 \pm \\
0.57^{\mathrm{b}}\end{array}$ & $6.5 \pm 0.53^{\mathrm{b}}$ \\
\hline Taste & $\begin{array}{c}8.6 \pm 0 . \\
70^{\mathrm{a}}\end{array}$ & $\begin{array}{l}8.2 \pm \\
0.79^{\mathrm{a}}\end{array}$ & $\begin{array}{c}7.3 \pm 0 . \\
82^{\mathrm{a}}\end{array}$ & $\begin{array}{c}6.7 \pm \\
0.95^{\mathrm{a}}\end{array}$ & $\begin{array}{l}3.8 \pm \\
0.63^{b}\end{array}$ & $\begin{array}{l}2.5 \pm \\
0.53^{\mathrm{c}}\end{array}$ & $1.4 \pm 0.52^{\mathrm{d}}$ & $\begin{array}{l}8.7 \\
\pm 0 . \\
48^{\mathrm{a}}\end{array}$ & $\begin{array}{l}8.2 \\
\pm 0 . \\
42^{\mathrm{a}}\end{array}$ & $\begin{array}{l}7.6 \\
\pm 0 . \\
52^{\mathrm{a}}\end{array}$ & $\begin{array}{c}7.2 \pm 0 . \\
92^{\mathrm{a}}\end{array}$ & $\begin{array}{c}7.1 \pm 0 . \\
88^{\mathrm{a}}\end{array}$ & $\begin{array}{l}6.9 \pm \\
0.74^{\mathrm{a}}\end{array}$ & $6.7 \pm 0.95^{\mathrm{a}}$ \\
\hline $\begin{array}{c}\text { Overall } \\
\text { appeara } \\
\text { nce }\end{array}$ & $\begin{array}{c}8.7 \pm 0 . \\
48^{\mathrm{a}}\end{array}$ & $\begin{array}{c}8.2 \pm \\
0.79 \\
\mathrm{a}\end{array}$ & $\begin{array}{c}7.3 \pm 0 . \\
68^{\mathrm{a}}\end{array}$ & $\begin{array}{c}6.5 \pm \\
0.71^{\mathrm{a}}\end{array}$ & $\begin{array}{c}4.5 \pm \\
0.97 \\
\text { b }\end{array}$ & $\begin{array}{l}3.1 \pm \\
0.57^{\mathrm{c}}\end{array}$ & $1.7 \pm 0.48^{\mathrm{d}}$ & $\begin{array}{l}8.7 \\
\pm 0 . \\
48^{\mathrm{a}}\end{array}$ & $\begin{array}{l}8.5 \\
\pm 0 . \\
53^{\mathrm{a}}\end{array}$ & $\begin{array}{l}8.3 \\
\pm 0 . \\
48^{\mathrm{a}}\end{array}$ & $\begin{array}{c}8.3 \pm 0 . \\
48^{\mathrm{a}}\end{array}$ & $\begin{array}{c}8.3 \pm 0 . \\
48^{\mathrm{a}}\end{array}$ & $\begin{array}{l}8.2 \pm \\
0.42^{\mathrm{a}}\end{array}$ & $8.1 \pm 0.57^{\mathrm{a}}$ \\
\hline $\begin{array}{c}\text { Remark } \\
\text { s }\end{array}$ & $\begin{array}{c}\text { Bright } \\
\text { red } \\
\text { colour } \\
\text {, fresh } \\
\text { aroma } \\
, \\
\text { crispy } \\
\text { textur } \\
\text { e }\end{array}$ & $\begin{array}{c}\text { Brig } \\
\text { ht } \\
\text { red } \\
\text { colo } \\
\text { ur, } \\
\text { fresh } \\
\text { arom } \\
\text { a, } \\
\text { crisp } \\
\text { y } \\
\text { textu } \\
\text { r }\end{array}$ & $\begin{array}{c}\text { Slight } \\
\text { colour } \\
\text { chang } \\
\text { e, }\end{array}$ & $\begin{array}{c}\text { Sligh } \\
\text { tly } \\
\text { soft, } \\
\text { colo } \\
\text { ur } \\
\text { brow } \\
\text { nish } \\
\text { red, } \\
\text { flavo } \\
\text { ur } \\
\text { good }\end{array}$ & $\begin{array}{c}\text { Colo } \\
\text { ur } \\
\text { brow } \\
\text { nish, } \\
\text { textu } \\
\text { re } \\
\text { soft, } \\
\text { flavo } \\
\text { ur } \\
\text { chan } \\
\text { ge }\end{array}$ & $\begin{array}{c}\text { Colo } \\
\text { ur } \\
\text { brow } \\
\text { nish, } \\
\text { textu } \\
\text { re } \\
\text { soft, } \\
\text { bad } \\
\text { odou } \\
\text { r }\end{array}$ & $\begin{array}{c}\text { Colour } \\
\text { brownish, } \\
\text { texture } \\
\text { more } \\
\text { softer,bad } \\
\text { odour }\end{array}$ & $\begin{array}{c}\text { Bri } \\
\text { ght } \\
\text { red } \\
\text { colo } \\
\text { ur, } \\
\text { fres } \\
\mathrm{h} \\
\text { aro } \\
\text { ma, } \\
\text { cris } \\
\text { py } \\
\text { text } \\
\text { ur }\end{array}$ & $\begin{array}{c}\text { Bri } \\
\text { ght } \\
\text { red } \\
\text { colo } \\
\text { ur, } \\
\text { fres } \\
\mathrm{h} \\
\text { aro } \\
\text { ma, } \\
\text { cris } \\
\text { py } \\
\text { text } \\
\text { ur }\end{array}$ & $\begin{array}{c}\text { Bri } \\
\text { ght } \\
\text { red } \\
\text { colo } \\
\text { ur, } \\
\text { fres } \\
\text { h } \\
\text { aro } \\
\text { ma, } \\
\text { cris } \\
\text { py } \\
\text { text } \\
\mathrm{u}\end{array}$ & $\begin{array}{c}\text { Slight } \\
\text { chang } \\
\text { e in } \\
\text { colour } \\
\text {, good } \\
\text { flavou } \\
\text { r, } \\
\text { taste }\end{array}$ & $\begin{array}{c}\text { Slight } \\
\text { chang } \\
\text { e in } \\
\text { colour } \\
\text {, good } \\
\text { flavou } \\
\text { r, } \\
\text { taste }\end{array}$ & $\begin{array}{c}\text { Sligh } \\
\mathrm{t} \\
\text { chan } \\
\text { ge in } \\
\text { colo } \\
\text { ur, } \\
\text { good } \\
\text { flavo } \\
\text { ur, } \\
\text { taste }\end{array}$ & $\begin{array}{l}\text { Slight } \\
\text { change in } \\
\text { colour, } \\
\text { good } \\
\text { flavour, } \\
\text { taste }\end{array}$ \\
\hline
\end{tabular}

Similar superscripts indicate non-significant difference at $\mathrm{P}>0.05$

Values are mean \pm S.D.

Tintometer colour readings for sandge samples packed in PET/PE and PET/Met. Poly/PE measured using Lovibond tintometer model $\mathrm{E}$ have been presented in Table 4. Tintometer colour units for Yellow and Blue showed changes over the entire storage period of 90 days, except for Red which remained almost constant. The degradation of colour was more in PET /PE packaged sandge as compared to the one in PET/Met.poly/PE pouch. For the product 
packaged in PET/PE, the units for dullness( the least value among R, Y, B) and yellowness increased, indicating colour fading, whereas the products packaged in PET/Met. Poly/PE showed a marginal increase in the units of dullness and yellowness indicating very little colour change. The changes may be contributed to the increase in non-enzymatic browning and decrease in carotenoids upon exposure to light during storage [27].The changes in colour units had significant effect on the quality of the product. Rao, et al. [28] also observed the effect of colour changes measured using Lovibond Tintometer on the quality of tomato powder and instant tomato pickle mix while Khedkaret al. [29] studied the effect of storage on colour for metkut, an pulse based food adjunct.

Table. 4: Colour measurement using Lovibond Tintometer during ambient temperature storage for 90 days

\begin{tabular}{|c|c|c|c|c|c|c|c|c|}
\hline Sample & $\begin{array}{c}\mathbf{R} / \mathbf{Y} / \\
\mathbf{B}\end{array}$ & $\begin{array}{c}\mathbf{0} \\
\mathbf{d a} \\
\mathbf{y}\end{array}$ & $\begin{array}{c}15 \\
\text { da } \\
y\end{array}$ & $\begin{array}{c}30 \\
\text { da } \\
\mathbf{y}\end{array}$ & $\begin{array}{c}45 \\
\text { da } \\
y\end{array}$ & $\begin{array}{c}60 \\
\text { da } \\
\mathbf{y}\end{array}$ & $\begin{array}{c}75 \\
\text { da } \\
\mathbf{y}\end{array}$ & $\begin{array}{c}90 \\
\text { da } \\
y\end{array}$ \\
\hline \multirow{3}{*}{ PET/PE } & $\mathrm{R}$ & 6.3 & 6.3 & 6.1 & 6.1 & 6.1 & 6.0 & 6.0 \\
\hline & Y & $\begin{array}{c}17 . \\
0\end{array}$ & $\begin{array}{c}18 . \\
0\end{array}$ & $\begin{array}{c}22 . \\
0\end{array}$ & $\begin{array}{c}25 . \\
0\end{array}$ & $\begin{array}{c}25 . \\
3\end{array}$ & $\begin{array}{c}26 . \\
5\end{array}$ & $\begin{array}{c}27 . \\
0\end{array}$ \\
\hline & B & 5.1 & 5.1 & 5.1 & 5.3 & 5.6 & 5.7 & 6.1 \\
\hline \multirow{3}{*}{$\begin{array}{c}\text { PET/M } \\
\text { et. } \\
\text { Poly/ } \\
\text { PE }\end{array}$} & $\mathrm{R}$ & 6.0 & 6.0 & 6.0 & 6.0 & 6.0 & 6.0 & 6.0 \\
\hline & $Y$ & $\begin{array}{c}17 . \\
0\end{array}$ & $\begin{array}{c}17 . \\
0\end{array}$ & $\begin{array}{c}17 . \\
0\end{array}$ & $\begin{array}{c}17 . \\
2\end{array}$ & $\begin{array}{c}17 . \\
4\end{array}$ & $\begin{array}{c}19 . \\
4\end{array}$ & $\begin{array}{c}23 . \\
0\end{array}$ \\
\hline & B & 5.5 & 5.5 & 5.6 & 6.0 & 6.0 & 6.0 & 6.0 \\
\hline
\end{tabular}

\section{CONCLUSION}

Sandge, a traditional food adjunct in Indian cuisine was standardized and the components, carrot (80\%), okra (9\%), green chilies $(3.5 \%)$, sesame seeds $(3.5 \%)$, coriander leaves and salt $(2 \%)$ each were found to be optimum. The prepared product was dried in a cabinet drier at $50^{\circ} \mathrm{C}$. It is nutritionally a good source of fiber, protein, vitamin $\mathrm{C}$, carotene and iron. The product when packaged in metallized polyester/ polythene laminated pouches had a shelf life of more than 90 days at ambient temperature conditions. The traditional method of sun drying, although being economical, is highly dependent on climatic conditions, is time consuming and offers no protection against dust from air, rodents and insects. The tray/cabinet drying method is faster, yields a hygienic product of consistent quality and retains sufficient amount of nutrients. PET/Metallized polyester/ polythene packaging extended the shelf life of the product and was attractive. The traditional food adjuncts sector has been dominated by cottage/ small scale industries. Limited production capacity, technological input and quality assurance has lead to restricted growth of the industry. Standardization of processes, nutritional properties, optimum packaging and storage solutions can help in technological upgradation, quality assurance, consistent and uninterrupted supply of these products, higher turnover and global market for these products.

\section{REFERENCES}

[1] Achaya, KT,(2000). The Story of Our Food , University Press India Limited, Hyderabad, India

[2] Srinivasan, K., (2010). Traditional Indian Functional Foods. Functional foods of the east, edited by Shi John, Ho, Chi-Tang, Shahidi, Fereidoon, CRC Press, 51-62

[3] Shastri PN, (2006). Changing face of traditional food adjuncts, Indian Food Industry, 25(6):73-77

[4] Tripathi, V,( 2013). Indian Thali: [ Rajasthani, Gujarati, Punjabi, Maharashtrian , South Indian] (vegetarian), Partridge India

[5] Mukadam, M., (2009).WalawanSanskruti, Retrieved from www.loksatta.com/daily/20090523/chchou.htm .Accessed on $25^{\text {th }}$ June, 2015

[6] Ogle Kamlabai, (1973). In:Ruchira, edn.6, StreeSakhiPrakashan ,Kirloskar Press ,Pune, India

[7] Kalra CL, Kulkarni SG and Berry SK, ( 1987), The carrot-A most popular root vegetable, Indian Food Packer, 41(6):46-73

[8] Varmudy V, (2014). Carrots: A call for increased cultivation, Facts for you, July, 22-23

[9] Suvarnakuta P, Devahastin S and Mujumdar AS, (2005). Drying kinetics and beta-carotene degradation in carrot undergoing different drying processes. Journal of Food Sc., 70: 520-526

[10] Koca N, Burdurlu SH \&Karadeniz F, ( 2007). Kinetics of colour changes in dehydrated carrots. Journal of Food Engineering, 78: 449-455,

[11] Sesame seeds nutrition facts,(2014).Retrieved from www.nutrition-and-you.com/sesame-seeds.html. Accessed on $28^{\text {th }}$ June, 2015

[12] Oguntona T, (1998) Green leafy vegetables. In: Quality of Plant Foods, Osagi A.U.;Eka O.U.(eds.).Post harvest Research Unit, University of Benin, Benin City, 120-130

[13] Mepba HD, Eboh L andBanigo DEB, (2008). Effects of processing treatments on the nutritive composition and consumer acceptance of some Nigerian edible leafy vegetables. Afr.Jour. Food Agri.Nutri.Dev., 7(1):1-18 
[14]Bolaji PT, Komolafe GO andAlli E, (2008). Drying characteristics of selected local vegetable. Nigerian Food Journal, 26(1): 138-143

[15] Chawla, S. and Thakur, M., (2013). Coriandrumsativum: A promising functional and medicinal food. Medicinal Plants - International Journal of Phytomedicines and Related industries, 5(2): $59-65$

[16] Sesame seeds, 2015. Retrieved from www.whfoods.com/genpage.php?tname=foodspice \&d bid=84 . Accessed on $28^{\text {th }}$ June, 2015

[17] Amerine MA, Pangborn RM and Roessler EB, (1965). In: Principles of Sensory Evaluation of Food, Academic Press, New York

[18] Kaur SS, Sandhu KS and Ahluwalia P, (2011). Effect of processing parameters on physico-chemical and culinary qualities of dried carrot slices, Journal of Food Science and Technology, April, 48(2): 159-166

[19]Ranganna S, (2001) Handbook of analysis and quality control for fruit and vegetable products, $2^{\text {nd }}$ edition, Tata-McGraw Hill

[20]Landrock AH and Proctor BE., ( 1951), Mod.Packag., 24 (6): 123

[21] Gopalan, C., Rama Sastri, B.V. and Balasubramanian, S., (2014) In : Nutritive Value of Indian Foods, National Institute of Nutrition (NIN), ICMR

[22] Tadesse TF, Abera S and Worku S, (2015) Nutritional and sensory properties of solar-dried carrot slices as affected by blanching and osmotic pre-treatments, International Journal of Food Science and Engineering, 5(1):24-32

[23] Jannat B, Oveisi MR, Sadeghi N, Hajimahmoodi M, Behzad M, Choopankari E \&Behfar AA., ( 2010). Effects of roasting temperature \& time on healthy neutraceuticals of antioxidants and total phenolic content in Iranian Sesame seeds(SesamumIndicum L.), Iran.J. Environmental Health.Sci. Eng.; 7(1): 97102

[24] Nema PK, Pendre NK, Sharma HP, Rathore SS and Kushwah SS, (2012). Effect of drying temperature and slice size on quality of dried okra(Abelmoschusesculentus (L) Moench), Journal of Food Science \& Technology, 49(3):378-381

[25]Rao DG, Jyothirmayi T \& Balaswamy K, ( 2004). Studies on preparation of curry leaf (Murrayakoenigii L. chutney powder, Food service Research International, 14: 175-187

[26] Satyanarayana A, Rao PP, Rao GN, Mala KS \&Balaswamy K, (2013). Preparation and storage stability of flaxseed chutney powder, a functional food adjunct, Journal of Food Science and Technology, JanFeb 50(1): 129-134

[27] Sra S.K., Sandhu K.S. and Ahluwalia P., (2011). Effect of processing parameters on physico-chemical and culinary quality of dried carrot slices, J Food Sci Tech,48(2): 159-166.

[28] Rao D.G., Narsing Rao, Prabhakar Rao, Balaswamy, P.G. and Balaswamy, K., ( 2011). Preparation of instant tomato pickle mix and evaluation of its storage stability, International Food Research Journal, 18: 589-593

[29] Khedkar,R., Shastri, P. and Bawa, A.S.,(2016).Standardization, chemical characterization and storage studies on Metkut, a pulse based Indian Traditional Food Adjunct, Food Science Research Journal, 7(1): 105-111 